\title{
Corrosion Behavior of MgO-C Refractory in Ferromanganese Slags
}

\author{
Hyungsic $\mathrm{UM}^{1)}$ Kyuyong $\mathrm{LEE}^{2)}{ }^{2)}$ Joo $\mathrm{CHOl}^{3)}$ and Yongsug $\mathrm{CHUNG}^{1) *}$ \\ 1) Department of Advanced Materials Engineering, Korea Polytechnic University, Siheung, 429-793 Republic of Korea. \\ 2) Department of Liberal Arts, Korea Polytechnic University, Siheung, 429-793 Republic of Korea. $\quad 3)$ Steelmaking
}

Research Group, POSCO, Pohang, 790-785 Republic of Korea.

(Received on July 20, 2011; accepted on September 14, 2011)

\begin{abstract}
The corrosion behavior of $\mathrm{MgO}-\mathrm{C}$ refractory used in oxygen blowing process in the manufacture of ferromanganese was investigated for different slag compositions. Finger Rotating Test (FRT) was introduced to observe the dependence of the corrosion behavior on various conditions: rotation speed, immersion time, slag, basicity, temperature and slag composition. As a result, the corrosion rate of $\mathrm{MgO}-\mathrm{C}$ refractory increases with increasing time and rotation speed. Also, the strong corrosion of $\mathrm{MgO}-\mathrm{C}$ refractory occurred when $\mathrm{MnO}$ is included in the slag composition. A kinetic study has been carried out with different slag contents.
\end{abstract}

KEY WORDS: MgO-C; refractory; ferromanganese; molten slag; corrosion.

\section{Introduction}

Magnesia-carbon $(\mathrm{MgO}-\mathrm{C})$ refractories have been one of the most important composite materials used in various steelmaking process. ${ }^{1,2)}$ Meanwhile, the $\mathrm{MgO}-\mathrm{C}$ refractory is used in oxygen blowing process for decarburization of ferromanganese.

Magnesia in $\mathrm{MgO}-\mathrm{C}$ refractory has the characteristics such as high melting point and high refractoriness. Carbon has the characteristics such as high thermal conductivity, low thermal expansion and low wettability of slag. When these two are combined, excellent resistances against thermal shock and corrosion are obtained. ${ }^{3,4)}$ However, the defect of the $\mathrm{MgO}-\mathrm{C}$ refractory, when in contact with the molten slag, essentially causes the corrosion of refractory. One of the corrosion factors of the $\mathrm{MgO}-\mathrm{C}$ refractory has been shown that carbon is oxidized by $\mathrm{MgO}$ according to the following reaction when the temperature increases and pressure decreases. ${ }^{1)}$

$$
\mathrm{MgO}_{(\mathrm{s})}+\mathrm{C}_{(\mathrm{s})}=\mathrm{Mg}_{(\mathrm{g})}+\mathrm{CO}_{(\mathrm{g})}
$$

Carbon of the $\mathrm{MgO}-\mathrm{C}$ refractory has properties of improved resistance to slag penetration into brick, but the susceptibility to oxidation is major weakness, leading to degradation of the $\mathrm{MgO}-\mathrm{C}$ refractory. ${ }^{5}$

A. Watanabe et $a .^{6-8)}$ have studied the formation of a decarburized layer due to oxidation of graphite by $\mathrm{FeO}$ in the slag or oxygen in the furnace atmosphere. The dissolution of the oxide is caused by the infiltration of slag into the decarburized layer and the reduction of oxide grain by high temperature reaction with carbon.

According to Cooper, ${ }^{9)}$ the corrosion of oxides occurs by the penetration of the species in the fluid into the solid. When a liquid phase in contact with refractory, the liquid phase penetrates into the pores of the refractory by capillary force and the species in the fluid are diffused into the refrac- tory through the grain boundaries. Then, the degradation of the refractory is resulted by the expansion or contraction of solid, or by change in the properties due to the diffusion of slag species into refractory.

Jansson et al. ${ }^{10)}$ showed in their experiments with a method similar to FRT that the corrosion rate of $\mathrm{MgO}-\mathrm{C}$ refractory increased with an increase in time, temperature and rod rotation speed. The observation was explained in terms of the dissolution of $\mathrm{MgO}$, which showed that the mass transfer of $\mathrm{MgO}$ into the slag is the rate-controlling process in the corrosion. The corrosion rate of the $\mathrm{MgO}-\mathrm{C}$ refractory decreased with the increase of $\mathrm{MgO}$ content in the slag because of the lower driving force for the dissolution of $\mathrm{MgO}$ and the higher slag viscosity.

Recently, the various corrosion mechanisms of the MgO$\mathrm{C}$ refractory due to the slag such as erosion, penetration and chemical decomposition have been studied. However, the corrosion mechanism of $\mathrm{MgO}-\mathrm{C}$ refractory used in the manufacture of ferromanganese has not been fully understood.

In this study, the corrosion behavior of the $\mathrm{MgO}-\mathrm{C}$ refractory used in the manufacture of ferromanganese was investigated through the FRT and the analysis of the kinetics of the corrosion behavior was presented.

\section{Experimental Procedure}

\subsection{Materials Preparation}

The $\mathrm{MgO}-\mathrm{C}$ refractories were cut from commercial refractory brick and processed to a cylindrical specimen of $50 \mathrm{~mm}$ in height and $20 \mathrm{~mm}$ in diameter. Table 1 shows the chemical composition of the $\mathrm{MgO}-\mathrm{C}$ refractory.

The synthetic slags were prepared by mixing $\mathrm{CaO}, \mathrm{SiO}_{2}$, $\mathrm{Al}_{2} \mathrm{O}_{3}$, and $\mathrm{MnO}$ melted in high frequency induction furnace. The chemical composition of the slags is specified in Table 2. The basicity was fixed to 0.8 . 
Table 1. Chemical composition of $\mathrm{MgO}-\mathrm{C}$ refractory (wt\%).

\begin{tabular}{ccccc}
\hline \multicolumn{5}{c}{ Composition (wt\%) } \\
\hline $\mathrm{MgO}$ & $\mathrm{SiO}_{2}$ & $\mathrm{Fe}_{2} \mathrm{O}_{3}$ & $\mathrm{CaO}$ & $\mathrm{C}$ \\
82.18 & 0.26 & 0.02 & 0.54 & 17 \\
\hline
\end{tabular}

Table 2. Chemical composition of the slag (wt\%).

\begin{tabular}{cccccc}
\hline \multicolumn{5}{c}{ Composition $(\mathrm{wt} \%)$} & Basicity (C/S) \\
\hline $\mathrm{No}$. & $\mathrm{CaO}$ & $\mathrm{SiO}_{2}$ & $\mathrm{Al}_{2} \mathrm{O}_{3}$ & $\mathrm{MnO}$ & \\
1 & 34 & 66 & & & 0.5 \\
2 & 45 & 55 & & & 0.8 \\
3 & 52 & 48 & & & 1.1 \\
4 & 40 & 50 & 10 & & 0.8 \\
5 & 36 & 44 & 20 & & 0.8 \\
6 & 27 & 33 & 40 & & 0.8 \\
7 & 27 & 33 & 10 & 30 & 0.8 \\
\hline
\end{tabular}

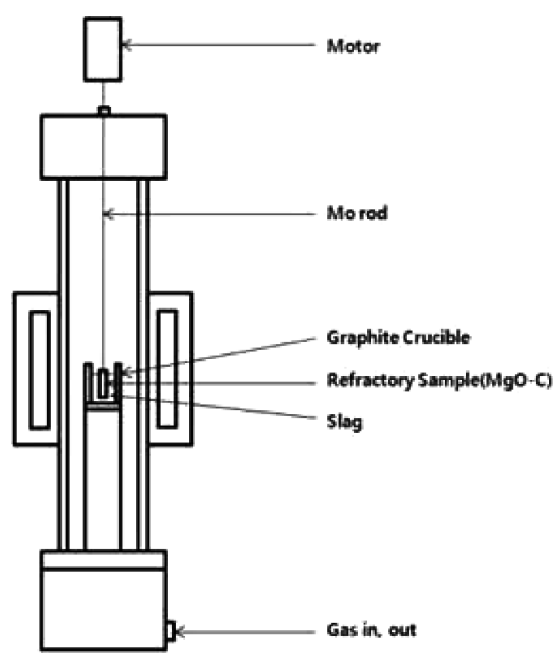

Fig. 1. Experimental apparatus.

\subsection{Finger Rotation Test}

Figure 1 schematically illustrates the experimental apparatus used to study the corrosion behavior of $\mathrm{MgO}-\mathrm{C}$ refractory and molten slag system.

The synthetic slag of $130 \mathrm{~g}$ was filled in a graphite crucible (diameter $50 \mathrm{~mm}$, height $150 \mathrm{~mm}$ ) and heated in a high-temperature vertical tube furnace under an Ar atmosphere. The $\mathrm{MgO}-\mathrm{C}$ refractory specimen was glued to a 6$\mathrm{mm}$ diameter Mo rod using ceramic adhesive. When the temperature reached a desired value, the specimen was fully immersed into the molten slag and rotated for a determined time. The experimental conditions are summarized in Table 3.

\subsection{Corrosion Index Analysis Techniques}

Two different corrosion indexes were used: 1) reaction area when the radius of the specimen is not significantly damaged, 2) radius reduction when the specimen is significantly damaged. The change in the appearance of the $\mathrm{MgO}-$ $\mathrm{C}$ refractory specimen immersed in $\mathrm{CaO}-\mathrm{SiO}_{2}$ slag is shown in Fig. 2. It can be seen that changes in appearance and weight are not significant. Horizontal cross-section of react-
Table 3. Test parameters.

\begin{tabular}{ccc}
\hline Temperature ${ }^{\circ} \mathrm{C}$ & Immersion time (min) & Rotation speed (rpm) \\
\hline $1450-1525-1600$ & $60-120-240-360$ & $200-400-600$ \\
\hline
\end{tabular}

(a)

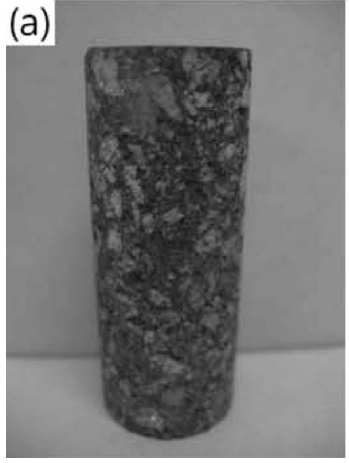

(b)

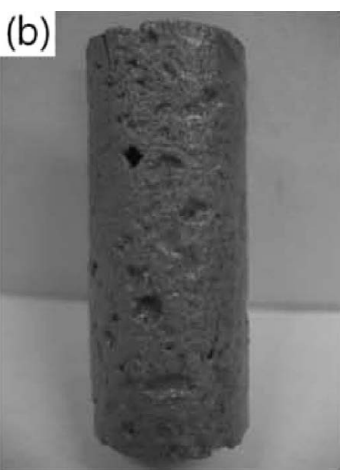

Fig. 2. The surface of the $\mathrm{MgO}-\mathrm{C}$ refractory specimen (a) before and (b) after immersed in $\mathrm{CaO}-\mathrm{SiO}_{2}$ slag at $1600^{\circ} \mathrm{C}$ for 360 $\min$.
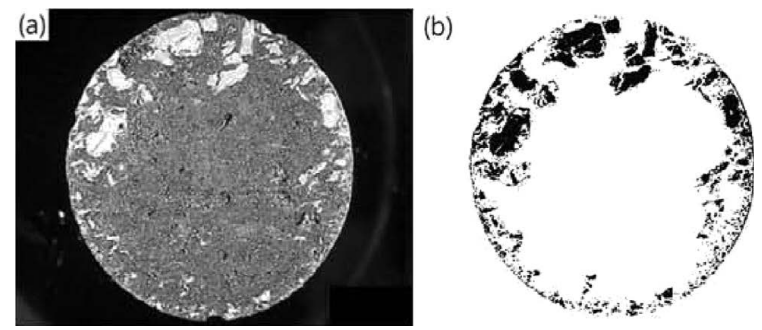

Fig. 3. Images showing the reaction area of the degraded $\mathrm{MgO}-\mathrm{C}$ refractory immersed in $\mathrm{CaO}-\mathrm{SiO}_{2}$ slag: (a) actual reaction cross-section, (b) reaction area extracted by Image $\mathrm{J}$.
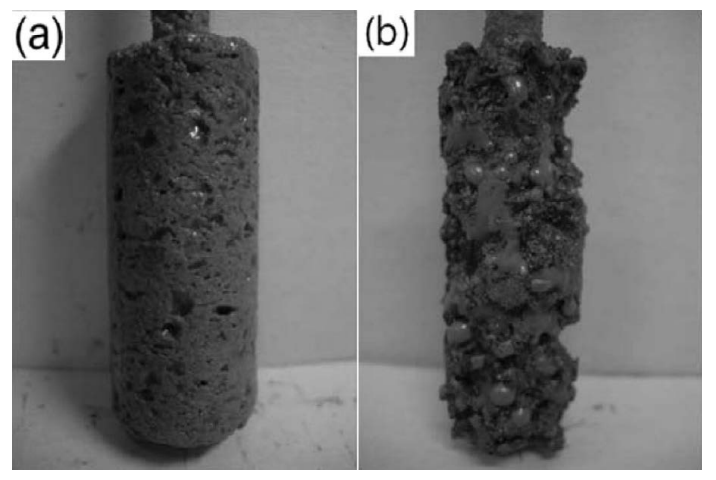

Fig. 4. Appearance of $\mathrm{MgO}-\mathrm{C}$ refractory specimens immersed (a) in $\mathrm{CaO}-\mathrm{SiO}_{2}-\mathrm{Al}_{2} \mathrm{O}_{3}$ slag at $1600^{\circ} \mathrm{C}$ for $360 \mathrm{~min}$ (b) in $\mathrm{CaO}-\mathrm{SiO}_{2}-\mathrm{Al}_{2} \mathrm{O}_{3}-\mathrm{MnO}$ slag at $1600^{\circ} \mathrm{C}$ for $360 \mathrm{~min}$.

ed $\mathrm{MgO}-\mathrm{C}$ refractory cut at $1 \mathrm{~cm}$ from the bottom was observed using an optical microscope (Fig. 3(a)). The reaction area as a corrosion index was measured using the image processing software Image J (Fig. 3(b)).

The surface of the $\mathrm{MgO}-\mathrm{C}$ refractory specimens immersed in $\mathrm{CaO}-\mathrm{SiO}_{2}-\mathrm{Al}_{2} \mathrm{O}_{3}$ slag and $\mathrm{CaO}-\mathrm{SiO}_{2}-\mathrm{Al}_{2} \mathrm{O}_{3}-$ $\mathrm{MnO}$ slag are shown in Figs. 4(a) and 4(b) respectively. It can be seen that the degradation of the $\mathrm{MgO}-\mathrm{C}$ refractory in these cases is very intense compared with the one immersed in $\mathrm{CaO}-\mathrm{SiO}_{2}$ slag (Fig. 2(b)). However, the observation of the horizontal cross-section of reacted specimens 

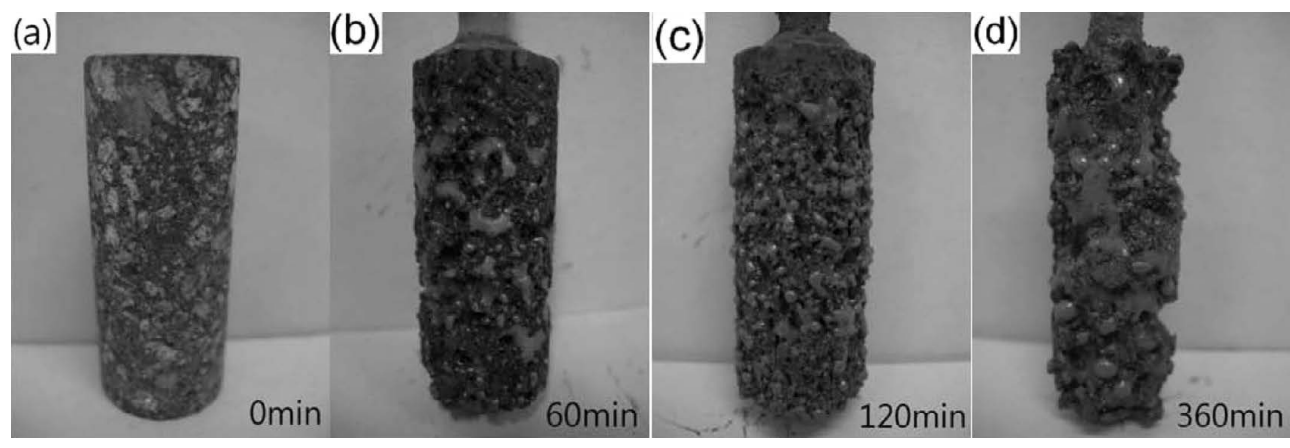

Fig. 5. Appearance of $\mathrm{MgO}-\mathrm{C}$ refractory specimens immersed in $\mathrm{CaO}-\mathrm{SiO}_{2}-\mathrm{Al}_{2} \mathrm{O}_{3}-\mathrm{MnO}$ slag at $1600^{\circ} \mathrm{C}$ for (a) 0 min (b) $60 \mathrm{~min}$ (c) $120 \mathrm{~min}$ and (d) $360 \mathrm{~min}$

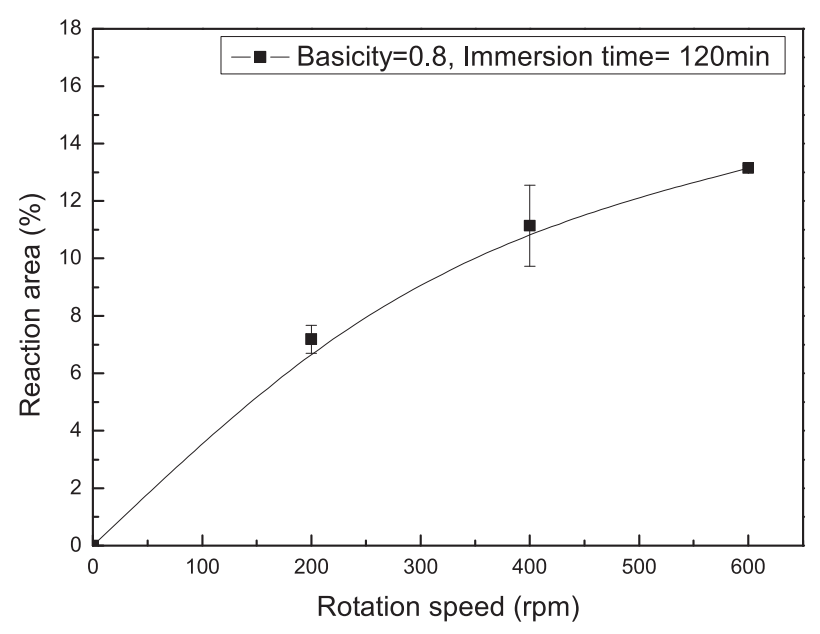

Fig. 6. A plot of reaction area as a function of rotation speed in $\mathrm{CaO}-\mathrm{SiO}_{2}$ slag composition at $1600^{\circ} \mathrm{C}$ for $120 \mathrm{~min}$.

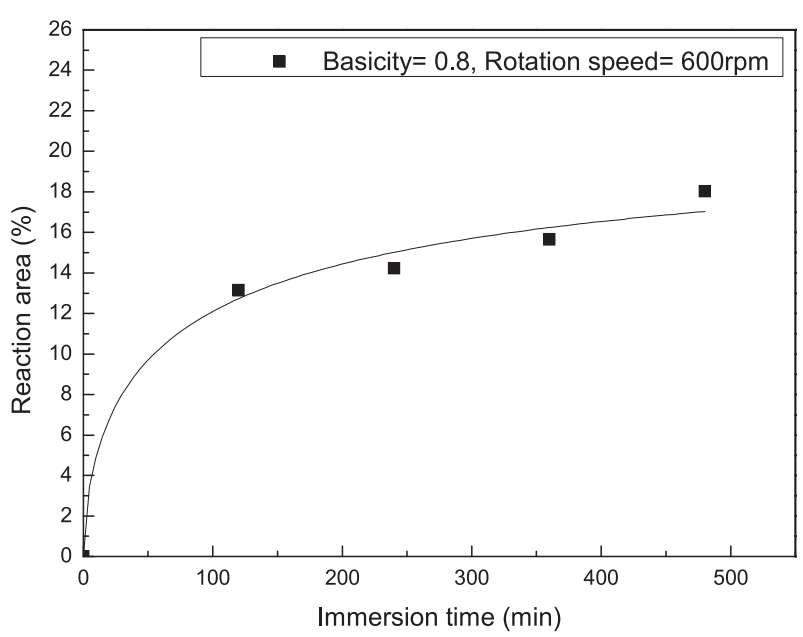

Fig. 7. A plot of reaction area as a function of immersion time in $\mathrm{CaO}-\mathrm{SiO}_{2}$ slag composition at $1600^{\circ} \mathrm{C}$.

\section{Results and Discussion}

decrease in the average radius of the $\mathrm{MgO}-\mathrm{C}$ refractory specimen was calculated by measuring the decrease of weight, and used as a corrosion index. The corrosion index can be expressed by:

$$
L=x-\left(\frac{w}{\rho h \pi}\right)^{\frac{1}{2}}
$$

where $L$ is the decrease of the average radius ( $\mathrm{cm}), x$ is the radius $(\mathrm{cm})$ of the specimen before immersed in slag, $w$ is the weight $(\mathrm{g})$ of the specimen after immersed in slag, $h$ is the height $(\mathrm{cm})$ of the specimen before immersed in slag, and $\rho$ is the bulk density of the specimen before immersed in slag.

It is assumed that the bulk density and height were fixed as can be seen in Figs. 5(b), 5(c) and 5(d). Eventually, the top and basal plane of the specimen did not decrease during immersed in slag as can be seen in Figs. 5(b), 5(c) and 5(d).

The chemical composition of the reaction area of the $\mathrm{MgO}-\mathrm{C}$ refractory reacted to $\mathrm{CaO}-\mathrm{SiO}_{2}$ slag was analyzed using wave dispersive spectroscopy (WDS). The spinel phase formed at the interface area of the $\mathrm{MgO}-\mathrm{C}$ refractory reacted to $\mathrm{CaO}-\mathrm{SiO}_{2}-\mathrm{Al}_{2} \mathrm{O}_{3}$ slag was identified byX-ray diffraction (XRD) analysis. The reaction product at the surface of the $\mathrm{MgO}-\mathrm{C}$ refractory reacted to $\mathrm{CaO}-\mathrm{SiO}_{2}-\mathrm{Al}_{2} \mathrm{O}_{3}-\mathrm{MnO}$ slag was analyzed usingenergy dispersive spectroscopy (EDS).

\subsection{Corrosion Behavior with $\mathrm{CaO}_{-} \mathrm{SiO}_{2} \mathrm{Slag}_{\mathrm{C}} \mathrm{Composi-}$ tion}

First, the dependence of the corrosion behavior of $\mathrm{MgO}-$ $\mathrm{C}$ refractory on rotation speed, immersion time, and slag basicity was investigated in the case of the simplest slag composition: $\mathrm{CaO}-\mathrm{SiO}_{2}$.

The reaction area as a function of rotation speed is plotted in Fig. 6. The reaction area of $\mathrm{MgO}-\mathrm{C}$ refractory increases with increasing rotation speed. This implies that the mass transport of solute in the molten slag around $\mathrm{MgO}-\mathrm{C}$ refractory increases with increasing rotation speed. ${ }^{10)}$

The reaction area as a function of immersion time is shown in Fig. 7. The reaction of area of $\mathrm{MgO}-\mathrm{C}$ refractory rapidly increases at the beginning and it slowly increases after 100 minutes. This appears that the interface grain is rapidly reacted around the circumference at the beginning and the reacted area is slowly increased through solid diffusion.

Figure 8 shows the reaction area as a function of basicity in $\mathrm{CaO}-\mathrm{SiO}_{2}$ slag composition. The reaction area of $21.1 \%$ was obtained at the basicity of 0.5 . The reaction area was remained to be $18 \%$ and $17.6 \%$ at the basicity of 0.8 and 1.1 . Considering error of reaction area measurement about $3 \%$, the $\mathrm{MgO}-\mathrm{C}$ refractory is affected little by increasing basicity in $\mathrm{CaO}-\mathrm{SiO}_{2}$ slag composition. 


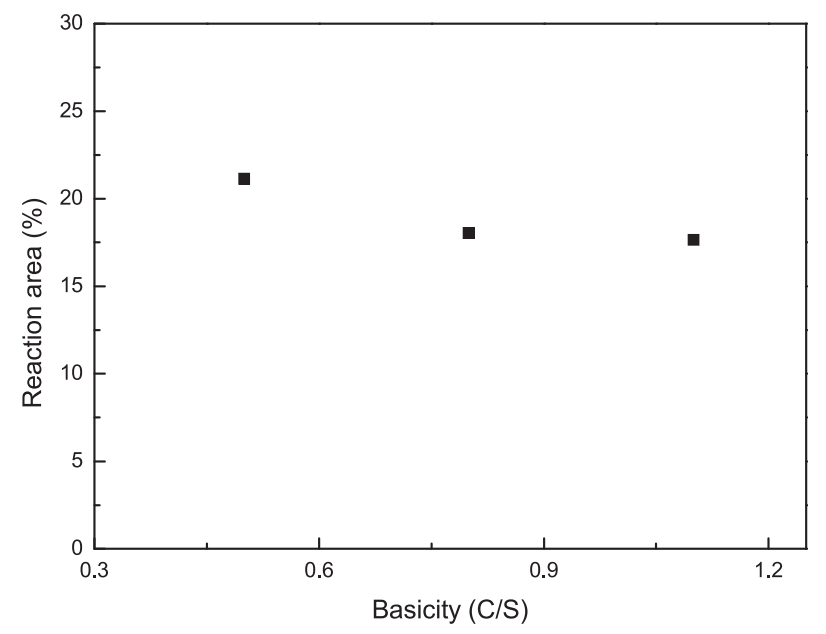

Fig. 8. A plot of reaction area as a function of basicity in $\mathrm{CaO}-$ $\mathrm{SiO}_{2}$ slag composition at $1600^{\circ} \mathrm{C}$ for $120 \mathrm{~min}$.

Table 4. Chemical composition of reaction area (w\%).

\begin{tabular}{ccc}
\hline \multicolumn{3}{c}{ Composition (wt\%) } \\
\hline $\mathrm{CaO}$ & $\mathrm{SiO}_{2}$ & $\mathrm{MgO}$ \\
38.8 & 50.9 & 10.3 \\
31.3 & 52.8 & 15.9 \\
\hline
\end{tabular}

The chemical composition of the reaction area of the specimen in Fig. 3(a) was determined by EPMA /WDS measurement and by referring to the Slag Atlas ${ }^{11)}$ (Table 4). The reaction area was composed of ternary oxides consisting of $\mathrm{CaO}, \mathrm{SiO}_{2}$ and $\mathrm{MgO}$. "Akermanite $\left(2 \mathrm{CaO} \cdot \mathrm{MgO} \cdot 2 \mathrm{SiO}_{2}\right)$ " or "Diopside $\left((\mathrm{Ca}, \mathrm{Mg}) \mathrm{O} \cdot \mathrm{MgO} \cdot 2 \mathrm{SiO}_{2}\right)$ " phase is mostly expected due to the penetration of slag or diffusion of ions at high temperature.

\subsection{Corrosion Behavior with $\mathrm{CaO}-\mathrm{SiO}_{2}-\mathrm{Al}_{2} \mathrm{O}_{3} \mathrm{Slag}$ Composition}

The decrease in the radius of the $\mathrm{MgO}-\mathrm{C}$ refractory after the reaction as a function of $\mathrm{Al}_{2} \mathrm{O}_{3}$ content in $\mathrm{CaO}-\mathrm{SiO}_{2}-$ $\mathrm{Al}_{2} \mathrm{O}_{3}$ slag composition is plotted in Fig. 9. The concentration of $\mathrm{Al}_{2} \mathrm{O}_{3}$ was determined by considering the saturation based on the Slag Atlas. ${ }^{12)}$ Figure 9 shows that the decrease in the radius occurred with 0 wt. $\%$ and 10 wt. $\% \mathrm{Al}_{2} \mathrm{O}_{3}$ content but not with $20 \mathrm{wt} . \%$ and over.

The XRD analysis of the surface of the $\mathrm{MgO}-\mathrm{C}$ refractory reacted to $\mathrm{CaO}-\mathrm{SiO}_{2}-\mathrm{Al}_{2} \mathrm{O}_{3}$ slag with different $\mathrm{Al}_{2} \mathrm{O}_{3}$ content is presented in Fig. 10. According to this XRD analysis, there is formation of a spinel phase on the surface of the $\mathrm{MgO}-\mathrm{C}$ refractory when $\mathrm{Al}_{2} \mathrm{O}_{3}$ content in the slag is 20 wt. $\%$ and over, but the spinel phase does not form when $\mathrm{Al}_{2} \mathrm{O}_{3}$ content in the slag is less than $20 \mathrm{wt} . \%$. This implies that the formed spinel phase prevents the corrosion of the $\mathrm{MgO}-\mathrm{C}$ refractory. In addition, the $\mathrm{Al}_{2} \mathrm{O}_{3}$ content in $\mathrm{CaO}-$ $\mathrm{SiO}_{2}-\mathrm{Al}_{2} \mathrm{O}_{3}$ slag causes the increase of viscosity ${ }^{12)}$ resulting in low mass transfer coefficient of $\mathrm{MgO}$ in the slag, which also reduces the corrosion of the refractory.

\subsection{Corrosion Behavior with $\mathrm{CaO}-\mathrm{SiO}_{2}-\mathrm{Al}_{2} \mathrm{O}_{3}-\mathrm{MnO}$ Slag Composition}

Next, the corrosion behavior of the refractory was inves-

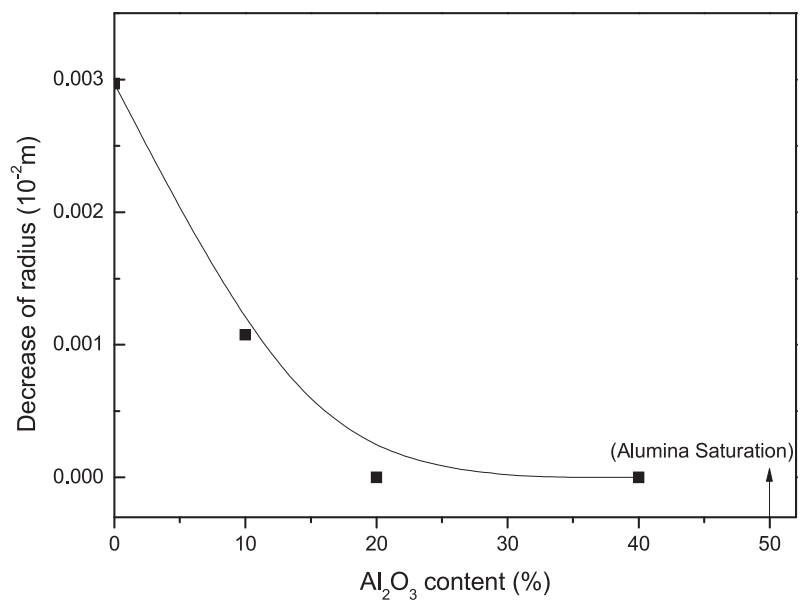

Fig. 9. A plot of the decrease in radius as a function of concentration of $\mathrm{Al}_{2} \mathrm{O}_{3}$ in $\mathrm{CaO}-\mathrm{SiO}_{2}-\mathrm{Al}_{2} \mathrm{O}_{3}$ slag at $1600^{\circ} \mathrm{C}$ for 360 $\min$.

tigated for $\mathrm{CaO}-\mathrm{SiO}_{2}-\mathrm{Al}_{2} \mathrm{O}_{3}-\mathrm{MnO}$ slag composition, which is important because it is the slag composition for actual ferromanganese manufacturing operation condition.

\subsubsection{The Effect of Slag Composition in the Corrosion Behavior}

The appearance of the $\mathrm{MgO}-\mathrm{C}$ refractory immersed in $\mathrm{CaO}-\mathrm{SiO}_{2}-\mathrm{Al}_{2} \mathrm{O}_{3}-\mathrm{MnO}$ slag is shown in Fig. 4(b). The degradation of $\mathrm{MgO}-\mathrm{C}$ refractory was very intense compared with the $\mathrm{MgO}-\mathrm{C}$ refractory immersed in $\mathrm{CaO}-\mathrm{SiO}_{2}$ slag or $\mathrm{CaO}-\mathrm{SiO}_{2}-\mathrm{Al}_{2} \mathrm{O}_{3}$ slag (shown in Figs. 2(b) and 4(a) respectively). The reaction product at the surface of the reacted $\mathrm{MgO}-\mathrm{C}$ refractory was observed by EPMA/EDS. Table $\mathbf{5}$ shows the chemical composition of reaction product at the $\mathrm{MgO}-\mathrm{C}$ refractory surface.

The result shows high content of Mn at the surface of the reacted $\mathrm{MgO}-\mathrm{C}$ refractory. This observation indicates that the carbon of the $\mathrm{MgO}-\mathrm{C}$ refractory was oxidized by the reaction with easily reducible $\mathrm{MnO}$ in the slag according to the following reaction.

$$
\mathrm{MnO}_{(\mathrm{l})}+\mathrm{C}(\mathrm{MgO}-\mathrm{C})=\mathrm{Mn}_{(\mathrm{l})}+\mathrm{CO}_{(\mathrm{g})}
$$

And, when $\mathrm{MnO}$ is added, the melting temperature of the slag is decreased ${ }^{12)}$ resulting in the increase of corrosion. Both reasons significantly affect the corrosion rate of $\mathrm{MgO}-$ C refractory.

Figure 11 shows a plot of decrease in the radius as a function of immersion time for different slag compositions. The decrease rates of the radius are calculated for the three slag compositions in Eqs. (4), (5) and (6).

$$
\begin{array}{r}
\frac{\mathrm{d} r}{\mathrm{~d} t}\left(\mathrm{CaO}-\mathrm{SiO}_{2}\right)=1.08 \times 10^{-7} \mathrm{~m} / \mathrm{min} \ldots \ldots \ldots . . . \\
\frac{\mathrm{d} r}{\mathrm{~d} t}\left(\mathrm{CaO}-\mathrm{SiO}_{2}-\mathrm{Al}_{2} \mathrm{O}_{3}\right)=2.98 \times 10^{-8} \mathrm{~m} / \mathrm{min} . \\
\frac{\mathrm{d} r}{\mathrm{~d} t}\left(\mathrm{CaO}-\mathrm{SiO}_{2}-\mathrm{Al}_{2} \mathrm{O}_{3}-\mathrm{MnO}\right)=7.30 \times 10^{-6} \mathrm{~m} / \mathrm{min}
\end{array}
$$

The highest corrosion rate of the $\mathrm{MgO}-\mathrm{C}$ refractory occurred in $\mathrm{CaO}-\mathrm{SiO}_{2}-\mathrm{Al}_{2} \mathrm{O}_{3}-\mathrm{MnO}$ slag composition (7.30 $\times$ $10^{-4} \mathrm{~cm} / \mathrm{min}$ ), the actual ferromanganese manufacturing operation condition. 

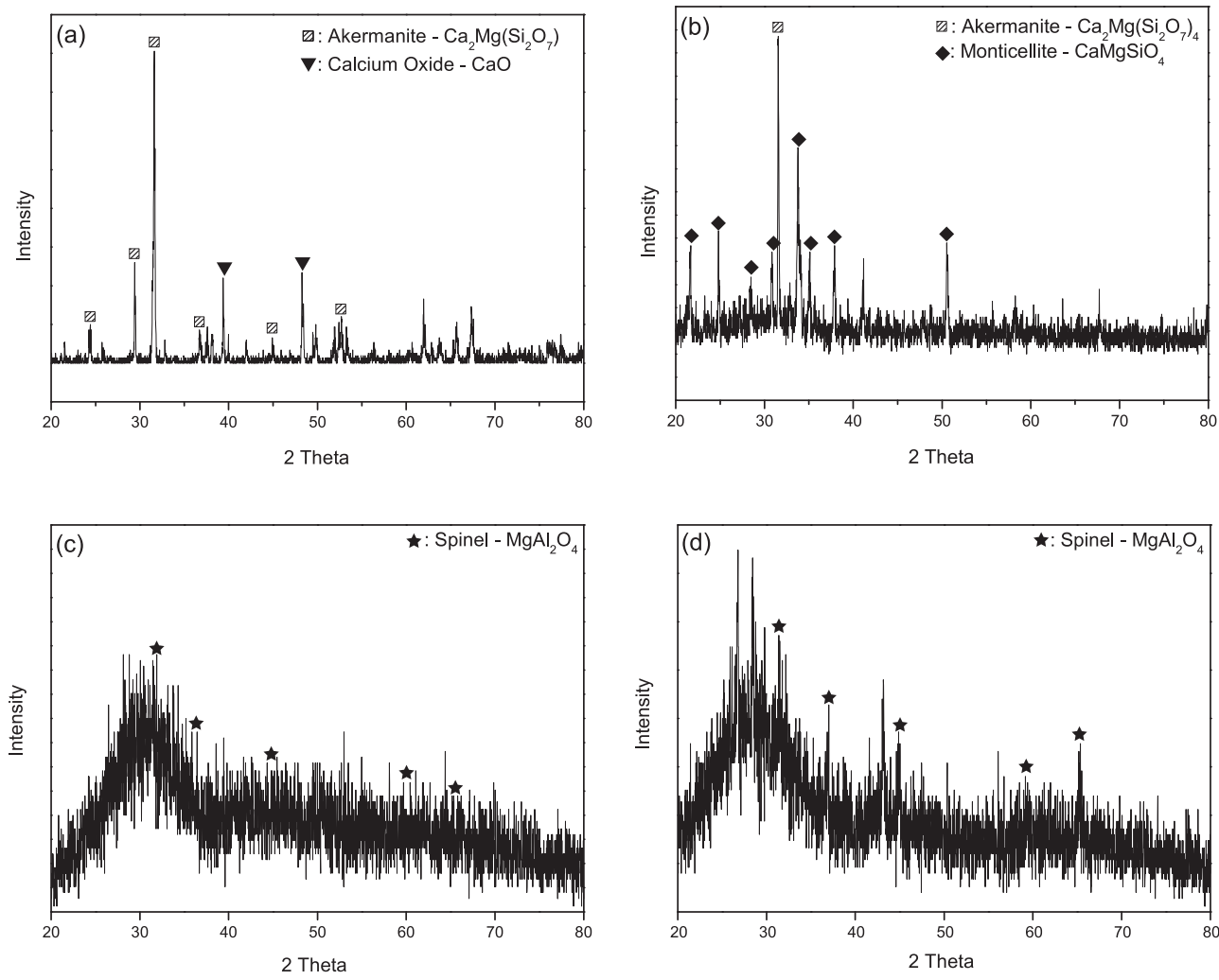

Fig. 10. X-ray patterns of $\mathrm{MgO}-\mathrm{C}$ refractory in various $\mathrm{Al}_{2} \mathrm{O}_{3}$ content of $\mathrm{CaO}-\mathrm{SiO}_{2}-\mathrm{Al}_{2} \mathrm{O}_{3}$ slag composition at $1600{ }^{\circ} \mathrm{C}$ during 360 min: (a) 0 wt. $\% \mathrm{Al}_{2} \mathrm{O}_{3}$ content, (b) 10 wt. $\% \mathrm{Al}_{2} \mathrm{O}_{3}$ content, (c) 20 wt. $\% \mathrm{Al}_{2} \mathrm{O}_{3}$ content, (d) 40 wt. $\%$ $\mathrm{Al}_{2} \mathrm{O}_{3}$ content.

Table 5. Chemical composition of reaction product at $\mathrm{MgO}-\mathrm{C}$ refractory surface (wt.\%)

\begin{tabular}{cccc}
\hline \multicolumn{5}{c}{ Composition $(w t \%)$} \\
\hline $\mathrm{Mn}$ & $\mathrm{C}$ & $\mathrm{Si}$ & $\mathrm{O}$ \\
69.96 & 6.91 & 0.49 & 22.64 \\
\hline
\end{tabular}

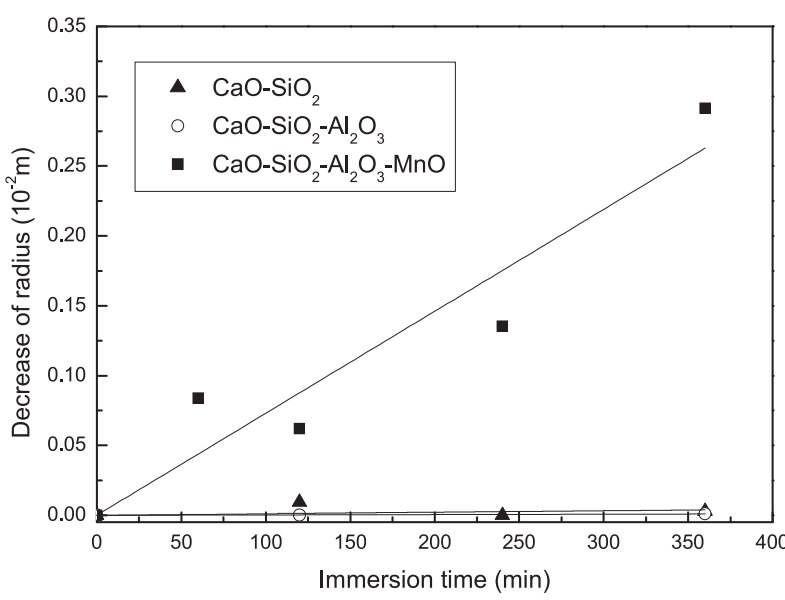

Fig. 11. A plot of decrease in the radius as a function of immersion time for different slag compositions at $1600^{\circ} \mathrm{C}$ showing the effect of slag composition on corrosion behavior.

3.3.2. Kinetic Analysis of Temperature Effect on the Corrosion Behavior

In order to show the effect of temperature on the corrosion behavior the decrease in the radius as a function of immersion time is presented in Fig. 12 for the case of $\mathrm{CaO}_{-}$

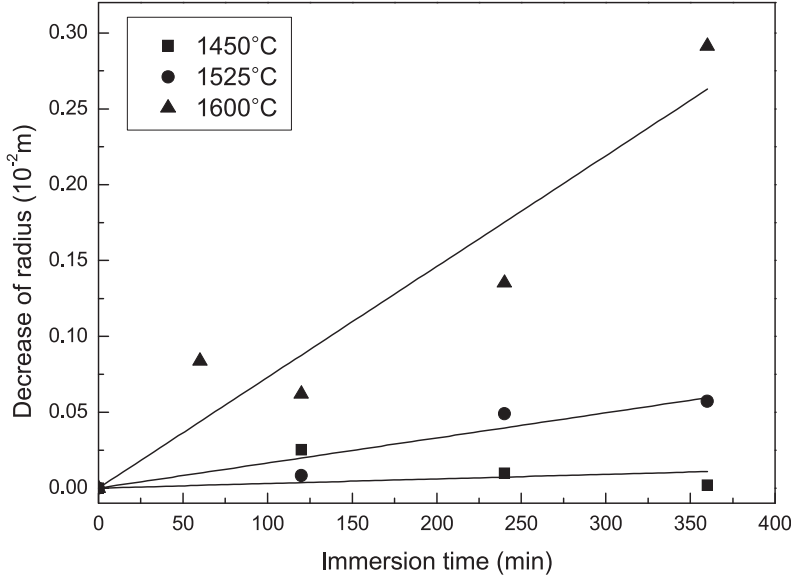

Fig. 12. Effect of temperature as function of immersion time in $\mathrm{CaO}-\mathrm{SiO}_{2}-\mathrm{Al}_{2} \mathrm{O}_{3}-\mathrm{MnO}$ slag composition.

$\mathrm{SiO}_{2}-\mathrm{Al}_{2} \mathrm{O}_{3}-\mathrm{MnO}$ slag composition. The decrease rate of the $\mathrm{MgO}-\mathrm{C}$ refractory radius increases with increasing temperature.

The mass transport coefficients $k$ can be calculated from the slope of Fig. 12 using Eq. (7).

$$
-\frac{\mathrm{d} r}{\mathrm{~d} t}=\frac{k}{100 \rho}\left\langle(\% \mathrm{MgO})_{\mathrm{s}} \rho_{\mathrm{s}}-(\% \mathrm{MgO})_{\mathrm{b}} \rho_{\mathrm{b}}\right\rangle
$$

where $\rho$ is the bulk density of the $\mathrm{MgO}-\mathrm{C}$ refractory, and $\rho_{s}$ and $\rho_{b}$ the slag density at the interface and the bulk, respectively. The density values $\left(\rho_{b}\right)$ of the slag and the saturation value of $\mathrm{MgO}(\% \mathrm{MgO})_{\mathrm{s}}$ in the slag for the calculation were determined from the Slag atlas. ${ }^{12}$ 


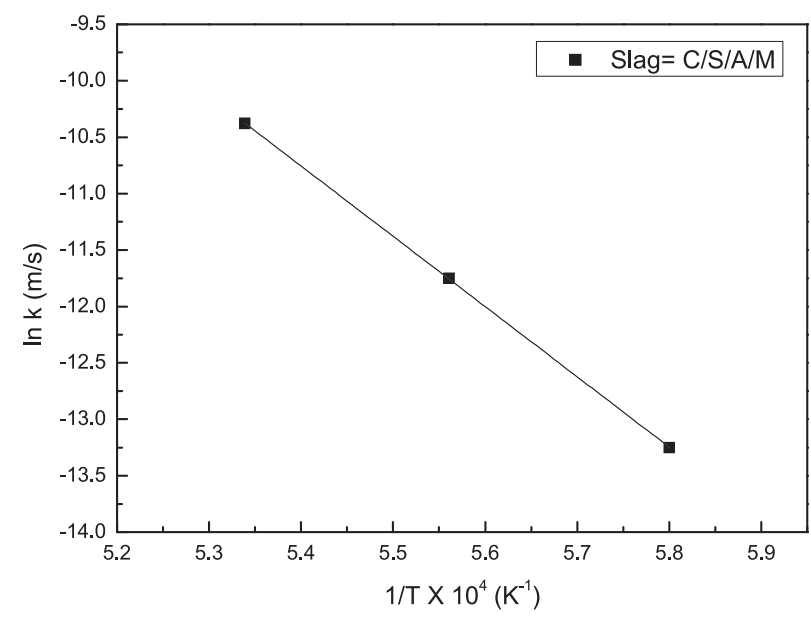

Fig. 13. Effect of temperature on mass transfer coefficient with $\mathrm{CaO}-\mathrm{SiO}_{2}-\mathrm{Al}_{2} \mathrm{O}_{3}-\mathrm{MnO}$ slag.

An Arrhenius equation ${ }^{13)}$ relating the mass transport coefficient $k$ and the temperature $T$, Eq. (8) and its logarithmic form, Eq. (9) are used to calculate the activation energy:

$$
\begin{aligned}
& \mathrm{k}=\mathrm{A} \cdot \exp \left(-\mathrm{E}_{\mathrm{a}} / \mathrm{RT}\right) \\
& \ln \mathrm{k}=-\frac{\mathrm{E}_{\mathrm{a}}}{\mathrm{RT}}+\ln \mathrm{A}
\end{aligned}
$$

where $k$ is the mass transport coefficient, $A$ is pre-exponential term, $T$ is the absolute temperature $(\mathrm{K}), R$ is the ideal gas constant $(\mathrm{J} / \mathrm{mol} \mathrm{K})$, and $E$ is the activation energy $(\mathrm{J} / \mathrm{mol})$.

Figure 13 shows a plot of the mass transport coefficient in $\log$ scale versus $1 / \mathrm{T}$ at $1450-1600^{\circ} \mathrm{C}$. The activation energy calculated from the slope was $123 \mathrm{~kJ} / \mathrm{mol}$.

\subsubsection{Kinetic Analysis of Dissolution Rate Effect on the} Corrosion Behavior

Under forced convection where the molten slag is agitat$\mathrm{ed}$, the dissolution rate for a rotating $\mathrm{MgO}-\mathrm{C}$ refractory can be expressed by the following equation: ${ }^{14)}$

$$
J=D\left(C_{s}-C_{m}\right) / 3.09(U / v x)^{1 / 2}(v / D)^{1 / 3}
$$

where $U$ is the bulk velocity of the fluid $(\mathrm{cm} / \mathrm{s}), v$ is the kinematic viscosity $\left(\mathrm{cm}^{2} / \mathrm{s}\right)$, and $x$ is the thickness of the interface $(\mathrm{cm})$. Using the values of $D$ and $v$ determined from the Slag atlas ${ }^{12)}$ and FACTSAGE, Eq. (10) gives $J=1.16 \times 10^{-3}$ $\mathrm{g} / \mathrm{cm}^{2} \mathrm{~s}$ for the $\mathrm{CaO}-\mathrm{SiO}_{2}-\mathrm{Al}_{2} \mathrm{O}_{3}-\mathrm{MnO}$ slag composition in Fig. 11. On the other hand, J can also be calculated by:

$$
J=-\rho \frac{\mathrm{d} r}{\mathrm{~d} t}
$$

where $\rho$ is the bulk density of the $\mathrm{MgO}-\mathrm{C}$ refractory, and $r$ is the radius of the refractory specimen. Using the experimental value of decrease rate in radius, the $J$ value of $1.97 \times$ $10^{-3} \mathrm{~g} / \mathrm{cm}^{2} \mathrm{~s}$ was obtained, which appeared in a agreement with the value calculated by Eq. (10). The difference between the calculated $\mathrm{J}$ and the measured $\mathrm{J}$ seems to be caused by the calculation assumption of Eq. (2), which may no longer validate at the severe corrosion condition as shown in Fig. 5(d).
The mass transport coefficient $\mathrm{k}$ could be calculated using Eisenberg's equation. ${ }^{15)}$

$$
k=0.0791 R e^{-0.33} S c^{-0.66} U
$$

where $R e$ is the Reynolds number $(=U d / v), S c$ is the Schmidt number $(=v / D), U$ is the periphery velocity of the cylinder and $\mathrm{D}$ is the diffusivity of $\mathrm{MgO}$ in the slag. Substituting the values for the $\mathrm{CaO}-\mathrm{SiO}_{2}-\mathrm{Al}_{2} \mathrm{O}_{3}-\mathrm{MnO}$ slag composition in Eq. (12), the $k$ value of $2.52 \times 10^{-3} \mathrm{~cm} / \mathrm{s}$ was obtained, which agrees with the experimental value $3.09 \times$ $10^{-3} \mathrm{~cm} / \mathrm{s}$ derived by Eq. (7).

\section{Conclusions}

(1) The corrosion of $\mathrm{MgO}-\mathrm{C}$ refractory in $\mathrm{CaO}-\mathrm{SiO}_{2}$ slag increases with increasing rotation speed and increasing immersion time for composition. The corrosion of $\mathrm{MgO}-\mathrm{C}$ refractory decreases with increasing basicity.

(2) $\mathrm{As} \mathrm{Al}_{2} \mathrm{O}_{3}$ content in $\mathrm{CaO}-\mathrm{SiO}_{2}-\mathrm{Al}_{2} \mathrm{O}_{3}$ slag increases, the corrosion of the $\mathrm{MgO}-\mathrm{C}$ refractory decreases. When $\mathrm{Al}_{2} \mathrm{O}_{3}$ content is $20 \mathrm{wt} . \%$ and over, a spinel phase forms on the surface of the refractory, which prevents the corrosion of the refractory. The addition of $\mathrm{Al}_{2} \mathrm{O}_{3}$ also reduces the corrosion of the refractory due to the increase of viscosity of the slag.

(3) The degradation of $\mathrm{MgO}-\mathrm{C}$ refractory immersed in $\mathrm{CaO}-\mathrm{SiO}_{2}-\mathrm{Al}_{2} \mathrm{O}_{3}-\mathrm{MnO}$ slag is very intense due to the oxidation of the carbon in $\mathrm{MgO}-\mathrm{C}$ refractory in the reaction with $\mathrm{MnO}$ in slag composition. The addition of $\mathrm{MnO}$ also enhances the corrosion of the refractory due to the decrease of the melting temperature of the slag.

(4) The agreement between the theoretical and experimental values implies that the corrosion rate is determined by mass transport.

\section{Acknowledgement}

This work was supported by the Industrial Strategy Technology Development (No. 10033389, Development of eFERA Technology) through a grant provided by the Ministry of Knowledge Economy.

\section{REFERENCES}

1) C. Schacht: Refractories handbook, CRC Press, Japan, (2004), 109.

2) C. Baudin: The Am. Ceram. Soc., (2001), 73.

3) H. Yasui, S. Hayashi, K. Nonobe, H. Takahashi and A. Watanable: Taikabutsu Overseas, 46 (1994), 454.

4) A. Watanabe, H. Takahashi, S. Takanaga, N. Goto, O. Matsuura and S. Yoshida: Taikabutsu Overseas, 10 (1989) 537.

5) E. H. Kim, H. C. Park, K. D. Oh, Y. B. Lee and T. H. Choi: An Introduction to Refractories Engineering, Dasung Press, Korea, (2002), 55.

6) A. Watanabe and Y. Takuechi: Taikabutsu Overseas, 1 (1981), 40

7) T. Horio, H. Fukuoka and K. Asano: Taikabutsu Overseas, 6 (1986), 11.

8) T. Suruga: Taikabutsu Overseas, 18 (1998), 5.

9) A. R. Cooper: Ceram. Eng. Sci., 2 (1982), 1063

10) S. Jansson: Scand. J Metall., 34 (2005), 283.

11) Slag Atlas, 1st ed., ed. by Verein Deuscher Eisenhüttenleute, Verlag Stahleisen m. b. h, Düsseldorf, Germany, (1981), 80.

12) Slag Atlas, 2nd ed., ed. by Verein Deutscher Eisenhüttenleute (VDEh), Düsseldorf, Germany, (1995), 156.

13) R. H. Petrucci and W. S. Harwood: General Chemistry, 6th ed., Macmillan, New York, (1993), 535.

14) W. E. Lee and S. Zhang: Int. Mater. Rev., 44 (1999), 77.

15) M. Eisenberg, C. W. Tobias and C. R. Wilke: Chem. Eng. Prog. Symp. Series, 16 (1955), 1. 